\title{
FAKTOR-FAKTOR YANG BERHUBUNGAN DENGAN KINERJA PETUGAS KESEHATAN PADA RUANG KELAS I DI RUMAH SAKIT BAHTERAMAS KOTA KENDARI
}

\author{
Factors That Are Related to The Performance of Health Officers In Class I Room In \\ Bahteramas Hospital, Kendari City
}

\author{
La Ode Muhamad Yasmin, Jenik Epik Juita \\ Program Studi Sarjana Kesehatan Masyarakat \\ Universitas Mandala Waluya \\ (armaithyasmin@gmail.com, 08114058088)
}

\begin{abstract}
ABSTRAK
Berdasarkan hasil wawancara diketahui bahwa masih kurangnya penghargaan dan perhatian dari pihak rumah sakit serta kurangnya termotivasi dalam bekerja. Tujuan penelitian ini adalah faktor yang berhubungan dengan kinerja petugas kesehatan pada ruang kelas I di Rumah Sakit Bahteramas Kota Kendari. Penelitian ini merupakan penelitian kuantitatif dengan pendekatan Cross Sectional Study. Populasi dalam penelitian ini berjumlah 102 orang dengan penarikan sampel secara Simple Random Sampling dengan jumlah sampel 51 orang. Metode analisis menggunakan uji statistik yakni Uji Chi Square dan Uji Phi. Hasil penelitian ini menunjukkan bahwa ada hubungan sedang antara disiplin kerja dengan kinerja petugas kesehatan (nilai $X^{2}$ hitung $=4,489$ dan $X^{2}$ tabel $=3,841$ ) dan uji $p h i=0,352$, ada hubungan lemah antara penghargaan dengan kinerja petugas kesehatan (nilai $\mathrm{X}^{2}$ hitung $=4,032$ dan $X^{2}$ tabel $\left.=3,841\right)$ dan $(p h i=0,247)$, ada hubungan sedang antara tanggung jawab dengan kinerja petugas kesehatan (nilai $X^{2}$ hitung $=4,975$ dan $X^{2}$ tabel $\left.=3,841\right)$ dan $(p h i=0,322)$ pada ruang kelas I di Rumah Sakit Umum Bahteramas Kota Kendari. Diharapkan kepada pihak Rumah sakit agar memberikan penghargaan kepada para petugas yang telah melaksanakan tugas dengan baik, baik dari segi pujian, piagam penghargaan ataupun insentif, memberikan pelatihan guna menambah pengetahuan petugas terkait tugas yang diberikan.
\end{abstract}

Kata Kunci: Disiplin kerja, penghargaan, tanggung jawab, kinerja

\begin{abstract}
Based on the results of the interview, it is known that there is still a lack of appreciation and attention from the hospital and a lack of motivation to work. The purpose of this study is the factors related to the performance of health workers in class I at Bahteramas Hospital, Kendari City. This research is a quantitative study with a Cross-Sectional Study approach. The population in this study amounted to 102 people with Simple Random Sampling with a sample size of 51 people. The method of analysis used statistical tests, namely the Chi-Square Test and the Phi Test. The results of this study indicate that there is a moderate relationship between work discipline and the performance of health workers $\left(X^{2}\right.$ count $=4,489$ and $X^{2}$ table $\left.=3,841\right)$ and the phi test $=0,352$, there is a weak relationship between reward and health worker performance $\left(X^{2}\right.$ count $=4.032$ and $X^{2}$ table $\left.=3,841\right)$ and (phi $=$ $0,247)$, there is a moderate relationship between responsibility and the performance of health workers (value $X^{2}$ count $=4,975$ and $X^{2}$ table $\left.=3,841\right)$ and $(p h i=0,322)$ in class 1 room at Bahteramas General Hospital Kendari City. It is hoped that the hospital will give awards to officers who have carried out their duties well in terms of praise, award certificates or incentives, provide training to increase the knowledge of officers regarding the tasks given.
\end{abstract}

Keywords: Work discipline, awards, responsibility, performance 


\section{PENDAHULUAN}

Rumah sakit merupakan salah satu unit pelayanan kesehatan masyarakat yang potensial dan perlu mendapatkan perhatian yang serius agar peranannya dalam pembangunan bangsa dan negara dapat terselenggara dengan baik dan dapat memberikan pelayanan dalam memperbaiki serta meningkatkan derajat kesehatan masyarakat. ${ }^{1}$

Keluhan terhadap pelayanan di rumah sakit sering kali terdengar langsung melalui media elektronik maupun media massa, yang biasanya menjadi sasaran utamanya adalah sikap atau tindakan dokter ataupun paramedis. Keluhan itu berupa pada sarana, kelambanan pelayanan kesehatan, persediaan obat dan sebagainya, tidak jarang dari pasien melebihkan peristiwa yang dialaminya dan ada saja orang yang tidak pernah puas betapun baiknya pelayanan atau upaya para petugas kesehatan dalam memberikan pelayanan. ${ }^{2}$

Kemampuan kerja petugas kesehatan perlu dioptimalkan dan dapat dilihat dari hasil kerjanya, berupa penguasaan ilmu pengetahuan dan teknologi, serta keterampilan dalam melaksanakan dan memberikan pelayanan kesehatan. Selain itu, seorang petugas kesehatan harus memiliki daya dorong dalam dirinya untuk melaksanakan tugas-tugas rutin di institusi pelayanan kesehatan dengan memanfaatkan pengetahuan yang dimiliki dan pengalaman yang diperoleh berdasarkan masa kerjanya. $^{3}$

Salah satu faktor yang menjadi indikator keberhasilan tujuan Rumah sakit adalah kinerja petugas (Sumber Daya Kesehatan). ${ }^{4}$
Kinerja petugas adalah hasil kerja yang terefleksi dalam cara merencanakan, melaksanakan dan menilai program pelayanan kesehatan yang intensitasnya dilandasi oleh etos kerja serta disiplin karyawan dalam proses pelayanan kesehatan dimana dipengaruhi oleh 3 faktor penentu antara lain: diseiplin kerja, penghargaan, dan tanggung jawab. Kinerja petugas yang baik akan menunjukkan pada tingkat kesempurnaan pelayanan kesehatan dalam menimbulkan rasa puas pada diri setiap pasien. Makin baik kinerja tersebut, makin baik pula mutu pelayanan kesehatan. ${ }^{5}$

Faktor pertama yang dapat mempengaruhi kinerja diantaranya adalah disiplin kerja karena apa yang menjadi tujuan organisasi akan sukar dicapai bila tidak ada disiplin kerja. ${ }^{6}$ Faktor lain adalah penghargaan juga merupakan salah satu aspek yang berarti bagi pegawai, karena bagi individu atau pegawai besarnya penghargaan mencerminkan ukuran nilai karya. Selain itu tanggung jawab adalah kemampuan untuk bertanggung jawab untuk dapat menyelesaikan seluruh tugas yang diberikan adanya dorongan yang kuat untuk mengambil suatu resiko, untuk dapat dipertanggungjawabkan sesuai dengan konsekuensi dan ketentuan yang ada seperti selalu melaksanakan pekerjaan tepat waktu dan pimpinan memberikan kewenangan dalm tugas. $^{7}$

Provinsi Sulawesi Tenggara dalam pelaksanaan kerja beberapa program masih belum tercapainya target standar pelayanan minimal. Hal tersebut dapat terjadi berdasarkan laporan Kepala Dinas Provinsi 
Sulawesi Tenggara dalam rapat kerja kesehatan daerah (Rakerkesda) identifikasi hambatan dan tantangan pembangunan kesehatan Provinsi Sulawesi Tenggara. Hambatan pembangunan kesehatan masih merupakan permasalahan klasik yang meliputi ketersediaan tenaga yang masih terbatas baik kuantitas maupun kualitas terutama ketersediaan sarana dan prasarana penunjang, manajemen pelayanan kesehatan yang belum berorientasi kebutuhan masyarakat, kemampuan kepemimpinan khususnya pemahanan manajemen yang masih sangat rendah, hal ini tersirat bahwa manajemen sumber daya manusia masih kurang khususnya peran pemimpin dalam memotivasi tenaga kesehatan agar bekerja lebih optimal. ${ }^{8}$

Berdasarkan data jumlah kunjungan di Rumah Sakit Bahteramas pada tahun 2016 sebanyak 17,711 orang, pada tahun 2017 sebanyak 17.102 orang, Pada tahun 2018 sebanyak 14.029 orang, sedangkan pada periode Januari sampai September 2019 sebanyak 12.359 orang. Data ini menunjukkan kunjungan pasien di Rumah Sakit Bahteramas mengalami penurunan. Penurunan jumlah kunjungan pasien merupakan salah satu aspek yang perlu dicari penyebabnya melalui penelitian. $^{9}$

Berdasarkan hasil wawancara langsung dengan bebarapa pasien yang sementara mendapatkan pelayanan kesehatan di Rumah Sakit Bahteramas, diketahui bahwa masih ada keluhan dari masyarakat tentang pelayanan kesehatan yang dinilai belum memuaskan. Hal ini terbukti dari hasil observasi peneliti yaitu4 orang mengatakan kurangnya disiplin kerja petugas kesehatan yaitu sebagian petugas pada saat pasien minta petolongan terkesan lambat. Selain itu petugas kesehatan mengatakan bahwa kurangnya penghargaan dari pihak rumah sakit dan kurangnya termotivasi dalam bekerja dan merasa perhatian yang diberikan oleh pimpinan terhadap petugas masih kurang. Berdasarkan permasalahan tersebut peneliti tertarik untuk melakukan penelitian dengan judul "Faktor-Faktor yang berhubungan dengan kinerja petugas kesehatan pada ruang kelas I di Rumah Sakit Bahteramas Kota Kendari.

\section{BAHAN DAN METODE}

Jenis penelitian yang digunakan adalah penelitian kuantitatif dengan rancangan Cross Sectional Study. ${ }^{10}$ Penelitian ini dilaksanakan April 2020di Rumah Sakit Bahteramas Kota Kendari. Populasi dalam penelitian ini adalah semua petugas kesehatan yang terdaftar pada ruang kelas I yang berjumlah 102 orang dan jumlah sampel sebanyak 51 oran. Pengumpulan data diperoleh melalui data sekunder dan data primer. Data akan diolah menggunakan SPSS 16.0 dengan analisis Univariat dan analisis Bivariat dengan rumus Chi Square dalam bentuk distribusi frekuensi yang kemudian dinarasikan secara deskriptif.

\section{HASIL}

Distribusi responden menurut pendidikan, umur dan masa kerja dapat dilihat pada Tabel 1. Distribusi menurut pendidikan responden pada ruang kelas I di RSU Bahteramas Provinsi Sulawesi Tenggara Tahun 2020 pada Tabel 1 menunjukkan bahwa 
dari 51 responden yang diteliti terdapat pendidikan tingkat D III sebanyak 37 responden $(72,5 \%)$ dan pendidikan tingkat $\mathrm{S} 1$ sebanyak 14 responden (27,5\%). Distribusi menurut umur responden pada ruang kelas I di RSU Bahteramas Provinsi Sulawesi Tenggara Tahun 2020 pada Tabel 1 menunjukkan bahwa dari 51 responden yang diteliti terdapat umur $>25$ tahun sebanyak 22 responden $(43,1 \%)$, dan pada umur $<25$ tahun sebanyak 29 responden $(56,9 \%)$. Distribusi menurut masa kerja responden pada ruang kelas di RSU Bahteramas Provinsi Sulawesi Tenggara Tahun 2020 pada Tabel 1 menunjukkan bahwa dari 51 responden yang diteliti terdapat masa kerja > 5 tahun sebanyak 22 responden $(43.1 \%)$, dan pada masa kerja $<5$ tahun sebanyak 29 responden $(56,9 \%)$.

Tabel 1. Distribusi Karakteristik Responden Pada Ruang Kelas I Di Rumah Sakit Umum Bahteramas Provinsi Sulawesi Tenggara Tahun 2020

\begin{tabular}{ccc}
\hline Karateristik & n (51) & \% \\
\hline Pendidikan & $\mathbf{n}$ & $\%$ \\
D III & 37 & 72.5 \\
S 1 & 14 & 27.5 \\
\hline
\end{tabular}

\section{Umur (Tahun)}

\begin{tabular}{ccc}
$>25$ & 22 & 43.1 \\
$<25$ & 29 & 56.9 \\
\hline Masa Kerja & & \\
$>5$ & 22 & 43.1 \\
$<5$ & 29 & 56.9 \\
\hline Total & $\mathbf{5 1}$ & $\mathbf{1 0 0}$ \\
\hline
\end{tabular}

Sumber: Data Primer, 2020

Adapun distribusi responden berdasarkan kinerja pada ruang kelas I di Rumah Sakit Umum Bahteramas Provinsi Sulawesi Tenggara tahun 2020 dapat dilihat pada Tabel 2. Pada Tabel 2 menunjukan bahwa jumlah responden yang kinerjanya cukup sebanyak 36 orang $(70,6 \%)$ dan kinerjanya kurang sebanyak 15 orang $(29,4 \%)$.

Tabel 2. Analisis Univariat

\begin{tabular}{lcc}
\hline \multicolumn{1}{c}{ Variabel } & \multicolumn{2}{c}{ Total } \\
\cline { 2 - 3 } & n & \% \\
\hline Kinerja & & \\
\hline Cukup & 35 & 68,6 \\
Kurang & 16 & 31,4 \\
\multicolumn{1}{c}{ Total } & $\mathbf{5 1}$ & $\mathbf{1 0 0}$ \\
\hline Disiplin Kerja & & \\
Cukup & 42 & 82,4 \\
Kurang & 9 & 17,6 \\
\multicolumn{1}{c}{ Total } & $\mathbf{5 1}$ & $\mathbf{1 0 0}$ \\
\hline Penghargaan & & \\
Cukup & 37 & 72,5 \\
Kurang & 14 & 27,5 \\
\multicolumn{1}{c}{ Total } & $\mathbf{5 1}$ & $\mathbf{1 0 0}$ \\
\hline Tanggung Jawab & & \\
Cukup & 31 & 60,8 \\
Kurang & 20 & 39,2 \\
\multicolumn{1}{c}{ Total } & $\mathbf{5 1}$ & $\mathbf{1 0 0}$ \\
\hline
\end{tabular}

Sumber: Data Primer, 2020

Selain itu distribusi responden berdasarkan disiplin kerja pada ruang kelas I di Rumah Sakit Umum Bahteramas Provinsi Sulawesi Tenggara tahun 2020 juga dapat dilihan pada Tabel 2 yang menunjukkan bahwa jumlah responden yang disiplin kerjanya cukup sebanyak 42 orang $(82,4 \%)$ dan disiplin kerjanya kurang sebanyak 9 orang $(17,6 \%)$ dan untuk distribusi responden berdasarkan penghargaan pada ruang kelas I di Rumah Sakit Umum Bahteramas Provinsi Sulawesi Tenggara Tahun 2020 pada Tabel 2 menunjukkan bahwa jumlah responden yang penghargaannya cukup sebanyak 37 orang 
$(72,5 \%)$ dan penghargaanya kurang sebanyak 14 orang $(27,5 \%)$. Sementara itu distribusi responden berdasarkan tanggung jawab pada ruang kelas I di Rumah Sakit Umum Bahteramas Provinsi Sulawesi Tenggara tahun 2020 pada Tabel 2 menunjukkan bahwa jumlah responden tanggung jawab cukup sebanyak 31 orang $(60,8 \%)$ dan tanggung jawabnya kurang sebanyak 20 orang $(39,2 \%)$.

Untuk melihat distribusi hubungan disiplin kerja Dengan kinerja petugas kesehatan pada ruang kelas I di Rumah Sakit Umum Bahteramas Provinsi Sulawesi Tenggara tahun 2020 dapat dilihat pada Tabel 3 yang menunjukkan bahwa dari 51 responden yang disiplin kerja cukup tetapi kinerja kurang sebanyak 10 responden $(19,6 \%)$ dan yang kinerja cukup sebanyak 32 responden $(62,7 \%)$. Sedangkan yang disiplin kerja kurang tetapi kinerja cukup sebanyak 3 responden $(5,9 \%)$ dan yang kinerja kurang sebanyak 6 responden $(11,8 \%)$. Hasil nilai uji statistik diperoleh nilai $\mathrm{X}_{\text {hit }}^{2}=4,489>\mathrm{X}_{\text {tab }}^{2}=3,841$, maka $\mathrm{H}_{\mathrm{o}}$ ditolak dan $\mathrm{H}_{\mathrm{a}}$ diterima artinya berarti ada hubungan antara disiplin kerja Dengan kinerja petugas kesehatan pada ruang kelas I di Rumah Sakit Umum Bahteramas Provinsi Sulawesi Tenggara Tahun 2020. Kemudian berdasarkan uji keeratan hubungan diperoleh nilai $P h i=$ 0,352 , artinya ada hubungan sedang antara kedua variabel.

Adapun hasil penelitian distribusi hubungan penghargaan dengan kinerja petugas kesehatan pada ruang kelas I di Rumah Sakit Umum Bahteramas Provinsi Sulawesi Tenggara tahun 2020 pada Tabel 3 menunjukkan bahwa dari 51 responden terdapat penghargaan cukup tetapi kinerja kurang sebanyak 9 responden $(17,6 \%)$ dan cukup kinerjanya sebanyak 28 responden (54,9\%). Sedangkan yang kurang penghargaan tetapi cukup kinerjanya sebanyak 7 responden $(13,7 \%)$ dan yang kurang kinerjanya sebanyak 7 responden $(13,7 \%)$. Hasil nilai uji statistik diperoleh nilai $\mathrm{X}_{\text {hit }}^{2}=4,032>\mathrm{X}_{\text {tab }}^{2}=3,841$, maka $\mathrm{H}_{\mathrm{o}}$ ditolak dan $\mathrm{H}_{\mathrm{a}}$ diterima artinya berarti ada hubungan antara penghargaan Dengan kinerja petugas kesehatan pada ruang kelas I di Rumah Sakit Umum Bahteramas Provinsi Sulawesi Tenggara Tahun 2020. Kemudian berdasarkan uji keeratan hubungan diperoleh nilai $p h i=0,247$, artinya ada hubungan lemah antara kedua variabel.

Distribusi hubungan tanggung jawab dengan kinerja petugas kesehatan pada ruang kelas I di Rumah Sakit Umum Bahteramas Provinsi Sulawesi Tenggara tahun 2020 dapat dilihat pada Tabel 3 yang menunjukkan bahwa dari 51 responden tanggung jawab cukup tetapi kinerja kurang sebanyak 6 responden $(11,8 \%)$ dan kinerja cukup sebanyak 25 responden $(49,0 \%)$. Sedangkan tanggung jawab kurang tetapi kinerja cukup sebanyak 10 responden $(19,6 \%)$ dan yang kinerja kurang sebanyak 10 responden $(19,6 \%)$. Hasil nilai uji statistik diperoleh nilai $\mathrm{X}_{\text {hit }}^{2}=4,975>\mathrm{X}_{\text {tab }}{ }=$ 3,841, maka $\mathrm{H}_{\mathrm{o}}$ ditolak dan $\mathrm{H}_{\mathrm{a}}$ diterima artinya berarti ada hubungan antara tanggung jawab dengan kinerja petugas kesehatan pada ruang kelas I di Rumah Sakit Umum Bahteramas Provinsi Sulawesi Tenggara Tahun 2020. Kemudian berdasarkan uji keeratan hubungan diperoleh nilai $P h i=0,322$, artinya ada hubungan sedang antara kedua variabel. 
Tabel 3. Analisis Bivariat

\begin{tabular}{|c|c|c|c|c|c|c|c|}
\hline \multirow{3}{*}{ Variabel } & \multicolumn{4}{|c|}{ Kinerja } & \multirow{2}{*}{\multicolumn{2}{|c|}{ Total }} & \multirow{3}{*}{ Hasil Uji Statistik } \\
\hline & \multicolumn{2}{|c|}{ Cukup } & \multicolumn{2}{|c|}{ Kurang } & & & \\
\hline & n & $\%$ & n & $\%$ & $\mathrm{n}$ & $\%$ & \\
\hline Disiplin Kerja & & & & & & & $\mathrm{X}_{\text {hit }}^{2}=4,489$ \\
\hline Cukup & 32 & 62,7 & 10 & 19,6 & 42 & 82,4 & $\mathrm{X}_{\mathrm{tab}}^{2}=3,841$ \\
\hline Kurang & 3 & 5,9 & 6 & 11,8 & 9 & 17,6 & Phi $=0,352$ \\
\hline Total & 35 & 68,6 & 16 & 31,4 & 51 & 100 & \\
\hline Penghargaan & & & & & & & $\mathrm{X}_{\mathrm{hit}}^{2}=4,032$ \\
\hline Cukup & 28 & 54,9 & 9 & 17,6 & 37 & 72,5 & $\mathrm{X}_{\mathrm{tab}}^{2}=3,841$ \\
\hline Kurang & 7 & 13,7 & 7 & 13.7 & 14 & 27,5 & $\mathrm{Phi}=0,247$ \\
\hline Total & 35 & 68,6 & 16 & 31,4 & 51 & 100 & \\
\hline Tanggung Jawab & & & & & & & \\
\hline Cukup & 25 & 49,0 & 6 & 11,8 & 31 & 60,8 & $\begin{array}{l}X^{2}{ }_{\text {hit }}=4,975 \\
X^{2}=3841\end{array}$ \\
\hline Kurang & 10 & 19,6 & 10 & 19,6 & 20 & 39,2 & $\begin{array}{c}X_{\text {tab }}=3,841 \\
P h i=0,322\end{array}$ \\
\hline Total & 35 & 68,6 & 16 & 31,4 & 51 & 100 & \\
\hline
\end{tabular}

Sumber: Data Primer, 2020

\section{PEMBAHASAN}

Disiplin kerja merupakan kemampuan responden dalam menaati peraturan-peraturan baik yang tertulis maupun yang tidak tertulis serta sanggup menjalankan dan tidak mengelak untuk menerima sanksi-sanksi apabila ia melanggar atas tugas dan wewenang yang diberikan. Menurut Hapsari, ada lima faktor dalam penilaian disiplin kerja yaitu kualitas disiplin kerja; meliputi datang dan pulang kerja tepat waktu; kuantitas pekerjaan meliputi volume dan kontribusi; kompensasi yang diperlukan meliputi saran, arahan atau perbaikan; lokasi tempat kerja atau tempat tinggal, dan konservasi meliputi penghormatan terhadap aturan. ${ }^{11}$

Hasil penelitian menunjukan bahwa dari 51 responden yang disiplin kerja cukup tetapi kinerja kurang sebanyak 10 responden $(19,6 \%)$. Hal ini disebabkan karena oleh pegawai disiplin waktu, mereka datang dan pulang tepat waktu dari jam yang telah ditentukan, ini terlihat dari kehadiran di tempat kerja masih menunjukkan disiplin kerja yang tinggi namun masih ada yang kinerjanya kurang karena banyak petugas kurang melaksanakan pekerjaannya tepat waktu sehingga mereka jarang turut andil dalam memberikan kontribusi disetiap kegiatan.

Tingkat disiplin seseorang petugas kesehatan dapat dilihat dari kepatuhan petugas pada jam kerja, ketaatan pada tata tertib dan peraturan yang ada, kepatuhan petugas kesehatan pada instruksi dari atasan, menggunakan dan memelihara fasilitas / peralatan kerja dengan baik dan menggunakan seragam sesuai ketentuan organisasi. Apabila disiplin kerjanya rendah kinerjanya akan rendah karena produktivitas kerja yang dihasilkan tidak maksimal. Disiplin merupakan suatu usaha yang dilakukan untuk menciptakan keadaan disuatu lingkungan kerja yang tertib, berdaya guna dan berhasil guna melalui sistem pengaturan itulah yang menjadi 
tolak ukur tinggi rendahnya prestasi kerja pegawai. $^{12}$

Sedangkan yang disiplin kerja kurang tetapi kinerja cukup sebanyak 3 responden $(5,9 \%)$ hal ini disebabkan oleh pegawai yang mempunyai jarak tempat tinggal yang jauh datang di rumah sakit tidak tepat pada waktu yang telah ditentukan tetapi hal tersebut digantikan oleh mereka dengan memperlihatkan keaktifan dan kecakapan mereka dalam melaksanakan dan menyelesaikan tugas yang mereka emban. Disiplin kerja adalah suatu alat yang digunakan para manejer untuk berkomunikasi dengan karyawan agar mereka bersedia untuk mengubah suatu perilaku serta sebagai suatu peraturan perusahaan dan norma-norma sosial yang berlaku. Tingkat disiplin seseorang pegawai dapat dilihat dari kepatuhan pegawai pada jam kerja, ketaatan pada tata tertib dan peraturan yang ada, kepatuhan pegawai pada instruksi dari atasan, menggunakan dan memelihara fasilitas / peralatan kerja dengan baik dan menggunakan seragam sesuai ketentuan organisasi. Apabila disiplin kerjanya rendah kinerjanya akan rendah karena produktivitas kerja yang dihasilkan tidak maksimal. ${ }^{13}$

Hasil nilai uji statistik diperoleh nilai $X_{\text {hit }}^{2}=4,489>X_{\text {tab }}^{2}=3,841$, maka $H_{o}$ ditolak dan $\mathrm{H}_{\mathrm{a}}$ diterima artinya berarti ada hubungan antara disiplin kerja dengan kinerja petugas kesehatan pada ruang kelas I di Rumah Sakit Umum Bahteramas Provinsi Sulawesi Tenggara Tahun 2020. Kemudian berdasarkan uji keeratan hubungan diperoleh nilai $\mathrm{Phi}=$ 0,352 , artinya ada hubungan sedang antara kedua variabel. Hasil penelitian ini didukung penelitian sebelumnya yaitu adanya hubungan secara positif dan signifikan antara disiplin dengan kinerja karyawan. ${ }^{14}$

Penghargaan merupakan persepsi petugas kesehatan tentang sistem penghargaan dan imbalan atas hasil pelaksanaan tugas yang dilakukan dalam bentuk insentif dan jenjang karier petugas kesehatan, rasa aman dalam pekerjaan, simbol status, penghargaan masyarakat dan harga diri. Hasil penelitian menunjukkan bahwa dari 51 responden terdapat penghargaan cukup tetapi kinerja kurang sebanyak 9 responden $(17,6 \%)$ hal ini disebabkan karena meskipun rumah sakit menyediakan promosi pekerjaan (penaikan jabatan) yang telah sesuai dengan prestasi kerja (PNS dan honorer) namun masih ada petugas yang kurang paham dengan pekerjaan yang diberikan sehingga pelayanan yang diberikan terkesan lambat. Akibatnyadengan statusnya sebagai Pegawai Negeri Sipil, mereka cukup puas dengan hanya mendapatkan gaji setiap bulannya. Penghargaan kinerja adalah sesuatu yang bersifat non finansial yang diberikan kepada karyawan sebagai penghargaan atas prestasi yang telah dicapainya. Dengan cara ini, karyawan akan sadar bahwa kinerjanya dihargai dan dinilai tinggi. ${ }^{15}$

Pemberian penghargaan berdasarkan kinerja dapat memberikan dampak positif terhadap perilaku karyawan, menimbulkan kepuasan kerja bagi karyawan, memberikan dampak positif terhadap kemampuan organisasi, mampu menghasilkan pencapaian tujuan yang telah dirancang dan 
mempertahankan lebih banyak karyawan yang mampu bekerja dengan prestasi tinggi. ${ }^{16}$ Sedangkan yang kurang penghargaan tetapi cukup kinerjanya sebanyak 7 responden $(13,7 \%)$. Hal ini disebabkan karena ketidakpuasan dari petugas kesehatan terhadap bentuk penghargaan yang diberikan pihak rumah sakit namun adanya kesadaran dari petugas itu sendiri tentang tugas yang diberikan sehingga petugas melakukan pekerjaanya dengan semangat. Selain itu ada pula yang mengatakan kurangnya pimpinan dalam memberikan kesempatan untuk mengikuti pelatihan untuk meningkatkan kemampuan petugas. Agar dapat melakukan manajemen kinerja dengan baik, organisasi harus merancang penghargaan yang baru. Untuk melakukannya maka harus dipertimbangkan bentuk penghargaan yang sebaiknya diberikan, siapa yang layak menerimanya, perlukah sesuatu yang bersifat desinsentif (hukuman) dan penilaian kinerja yang bagaimana digunakan apakah secara objektif atau secara subjektif. ${ }^{17}$

Hasil nilai uji statistik diperoleh nilai $\mathrm{X}_{\text {hit }}^{2}=4,032>\mathrm{X}_{\text {tab }}^{2}=3,841$, maka $\mathrm{H}_{\mathrm{o}}$ ditolak dan $\mathrm{H}_{\mathrm{a}}$ diterima artinya berarti ada hubungan antara penghargaan dengan kinerja petugas kesehatan pada ruang kelas I di Rumah Sakit Umum Bahteramas Provinsi Sulawesi Tenggara Tahun 2020. Kemudian berdasarkan uji keeratan hubungan diperoleh nilai $p h i=$ 0,247 , artinya ada hubungan lemah antara kedua variabel. Hasil penelitian ini sejalan dengan penelitian lain yang menunjukkan bahwa ada pengaruh penghargaan dengan kinerja petugas kesehatan pelaksana di Unit
Rawat Inap RS.Stella Maris Makassar. Peneliti berasumsi bahwa dalam hal pengakuan agar petugas mampu bekerja dan melaksanakan tugas dengan baik, pimpinan wajib memberikan penghargaan kepada yang bersangkutan, penghargaan itu dilakukan dengan berbagai bentuk seperti pujian yang dinyatakan dengan kata-kata, pujian yang dinyatakan secara tertulis dalam bentuk piagam, pemberian angka kredit yang berhubungan dengan karir pegawai dan pemberian barang yang bermanfaat bagi yang bersangkutan dalam melaksanakan tugas. ${ }^{18}$

Tanggung jawab merupakan suatu kewajiban yang timbul dalam diri petugas kesehatan untuk melaksanakan fungsi yang ditugaskan dengan sebaik-baiknya sesuai dengan pengarahan yang diterima, berkaitan dengan pelaksanaan pelayanan kesehatan meliputi: pelayanan kesehatanan tepat waktu sesuai kebutuhan penderita, tanggung jawab, pelaksanaan tugas sesuai jadwal yang diberikan, dan kewewenangan dalam melaksanakan pelayanan kesehatanan.

Hasil penelitian menunjukkan bahwa dari 51 responden yang tanggung jawab cukup tetapi kinerja krang sebanyak 6 responden $(11,8 \%)$ hal ini disebabkan karena petugas melaksanakan pelayanan tepat waktu sesuai kebutuhan penderita dan melaksanakan tugas sesuai dengan jadwal yang diberikan. Tanggung jawab menunjukkan kewajiban yang mengarah kepada kewajiban yang harus dilakukan untuk menyelesaikan pekerjaan secara professional. Manajer dan para staf harus memahami dengan jelas tentang fungsi tugas yang menjadi tanggung jawab masing- 
masing petugas kesehatan serta hasil yang ingin dicapai dan bagaimana mengukur kualitas kinerja stafnya. Petugas kesehatan yang profesional akan bertanggung jawab atas semua bentuk tindakan klinis kepetugas kesehatanan yang dilakukan dalam lingkup tugasnya. Sedangkan tanggung jawab kurang tetapi kinerja cukup sebanyak 10 responden $(19,6 \%)$, hal ini disebabkan karena masih rendahnya penilaian tanggung jawab yang dimiliki petugas kesehatan dapat berhubungan dengan pengetahuan petugas kesehatan tentang tugas dan tanggungjawabnya yang masih rendah seperti pemenuhan kebutuhan pelayanan setiap penderita merupakan tanggung jawab petugas. Tanggung jawab diperlukan untuk memenuhi kebutuhan dan kinerja yang ditampilkan guna memperoleh hasil pelayanan kepetugas kesehatanan yang berkualitas tinggi. Untuk mempertahankan petugas kesehatan yang bertanggung jawab, petugas kesehatan hendaknya mampu dan selalu melakukan introspeksi serta arahan pada dirinya sendiri (self-directed), merencanakan pengembangan diri secara kreatif dan senantiasa berusaha meningkatkan kualitas kinerjanya. Hal ini diperlukan agar mereka dapat mengidentifikasi elemen-elemen kritis untuk meningkatkan dan mengembangkan kinerja klinis mereka, guna memenuhi kepuasan pasen dan dirinya sendiri dalam pekerjaannya. Mencatat respon dan perkembangan pasen dengan lengkap dan benar merupakan salah satu tanggung jawab petugas kesehatan dalam melaksanakan tugasnya. ${ }^{19}$
Asumsi peneliti bahwa tanggung jawab dan akuntabilitas memerlukan dasar komitmen yang kuat dalam praktek ke petugas kesehatan untuk dapat mengembangkan kemampuannya secara mandiri. Disamping itu diperlukan kemampuan untuk dapat mengarahkan dirinya sendiri, sehingga dapat mengidentifikasikan elemen-elemen kritikal untuk pengembangan atau peningkatan kinerjanya dalam pelaksanaan tugasnya, dalam rangka mempertahankan tercapainya status profesionalnya. Melalui pembelajaran diri secara terus menerus, petugas kesehatan harus senantiasa meningkatkan pengetahuan, kemampuan, serta memelihara perilaku yang etis dan professional untuk menghasilkan kinerja klinis yang berkualitas tinggi. Hasil nilai uji statistik diperoleh nilai $X^{2}{ }_{\text {hit }}=4,975>$ $\mathrm{X}_{\text {tab }}^{2}=3,841$, maka $\mathrm{H}_{\mathrm{o}}$ ditolak dan $\mathrm{H}_{\mathrm{a}}$ diterima artinya berarti ada hubungan antara tanggung jawab dengan kinrja petugas kesehatan pada ruang kelas I di Rumah Sakit Umum Bahteramas Provinsi Sulawesi Tenggara Tahun 2020. Kemudian berdasarkan uji keeratan hubungan diperoleh nilai phi $=0,322$, artinya ada hubungan sedang antara kedua variabel. Hasil penelitian ini sejalan dengan penelitian La Ode Makta yang menunjukkan bahwa ada pengaruh tanggung jawab dengan kinerja petugas kesehatan pelaksana di Unit rawat inap RS.Stella Maris Makassar. ${ }^{20}$

\section{KESIMPULAN DAN SARAN}

Sesuai dengan hasil penelitian yang dilakukan, maka dapat disimpulkan sebagai ada hubungan sedang antara disiplin kerja dengan kinrja petugas kesehatan pada ruang 
kelas I di Rumah Sakit Umum Bahteramas Provinsi Sulawesi Tenggara Tahun 2020; Ada hubungan lemah antara penghargaan dengan kinerja petugas kesehatan pada ruang kelas I di Rumah Sakit Umum Bahteramas Provinsi Sulawesi Tenggara Tahun 2020 ; Ada hubungan sedang antara tanggungjawab dengan kinrja petugas kesehatan pada ruang kelas I di Rumah Sakit Umum Bahteramas Provinsi Sulawesi Tenggara Tahun 2020.

Diharapkan kepada pihak rumah sakit agar memberikan penghargaan kepada para petugas yang telah melaksanakan tugas dengan baik baik dari segi pujian, piagam penghargaan ataupun insentif, meberikan pelatihan guna menambah pengetahuan petugas tekait tugas yang diberikan. Diharapkan kepada petugas kesehatan agar petugas mampu bekerja dan melaksanakan tugas dengan baik, dan kepada peneliti selanjutnya lebih di fokuskan pada variabel lain yang berhubungan dengan kinerja petugas kesehatan khususnya dalam bidang pelayanan kesehatan serta dapat digunakan sebagai referensi tambahan dan pembanding, bagi yang melakukan penelitian dengan judul yang sama.

\section{UCAPAN TERIMA KASIH}

Ucapan terima kasih disampaikan kepada semua pihak yang telah membantu menyelesaikan penelitian ini dan ucapan terimakasih yang sebesar-besarnya penulis sampaikan pula pada pihak Yayasan Mandala Waluya Kendari yang telah memberikan kesempatan kepada kami dalam melaksanakan tridharma perguruan tinggi.

\section{DAFTAR PUSTAKA}

1. Kementerian Kesehatan RI. UndangUndang Republik Indonesia Nomor 36 Tentang Kesehatan, Jakarta; 2016.

2. Kursih S, Astrid N,. Pengaruh Kemampuan dan Motivasi Kerja Petugas Kesehatan Terhadap Kinerja Dalam Penerapan Program Manajemen Terpadu Balita Sakit Di Puskesmas Pasar Minggu. Jurnal Akademi Keperawatan Husada Karya Jaya. 2016:2(1):9-16.

3. Ridwan N, Darmawansyah, Indar. Pengaruh Gaya Kepemimpinan dan Kepuasan Kerja Terhadap Kinerja Pegawai Di RSUD Namlea Kabupaten Buru Provinsi Maluku. Jurnal Dunia Kesmas. 2017;2(4):19-22.

4. Akbar MI. Analysis Of The Needs Of General Practitioners In Public Health Centers Using Health Workload Method. Public Health of Indonesia. 2020;6(2):6369.

5. Aris B, Taher A, Hamidah N. Pengaruh Pelatihan, Kompensasi dan Disiplin Kerja Terhadap Prestasi Kerja Karyawan (Studi pada Kantor PT. PLN (Persero) Area Pelayanan dan Jaringan Malang). Jurnal Profit. 2017;6(2):12-18.

6. Syatriawan PP, Asmony $\mathrm{T}$, Nasir $\mathrm{M}$. Beberapa Faktor yang Mempengaruhi Disiplin Kerja Pegawai Negeri Sipil Puskesmas Se Kabupaten Dompu. Skripsi. Akademi Administrasi Rumah Sakit Mataram. Mataram; 2017.

7. Andri, Seno, Troena, Afnan E, Djumahir, Idrus. Pengaruh Gaya Kepemimpinan, 
Budaya Organisasi, Motivasi, Program

Diklat Terhadap Kinerja, dan Kepuasan

Kerja Karyawan. Jurnal Aplikasi

Manajemen. 2011;9(4):63-69.

8. Dinkes Provinsi Sulawesi Tenggara. Profil Kesehatan Sulawesi Tenggara. Kendari; 2018.

9. Dinas Kesehatan Kabupaten Buton Utara. Profil Rumah Sakit Bahteramas. Kendari; 2019.

10. Notoatmodjo S. Metodologi Penelitian Kesehatan. Jakarta: Rineka Cipta. 2014.

11. Hapsari. Hubungan Fasilitas Kerja, Disiplin Kerja dan Pengawasan terhadap Produktivitas Kerja Karyawan. Jurnal Universitas Muhammadiyah Surakarta. 2008;2(1):3-9.

12. Mawarni, Marpaung I, Hamid D, Iqbal M. Pengaruh Motivasi dan Disiplin Kerja Terhadap Kinerja Karyawan (Studi Pada Karyawan Rumah Sakit Reksa Waluya Mojokerto). Jurnal Administrasi Bisnis (JAB). 2014;15(2):13-19.

13. Setiawan, Agung. Pengaruh Disiplin Kerja dan Motivasi Terhadap Kinerja Karyawan pada Rumah Sakit Umum Daerah Kanjuruhan Malang. Jurnal Ilmu Manajemen. 2013;1(4):19-26.

14. Trialfiah, Muhni. Pengaruh Motivasi, Perilaku Pemimpin, dan Kesempatan Pengembangan Karir Terhadap Kinerja Karyawan (Survey pada Rumah Sakit Umum Daerah di Eks Karisidenan Surakarta). Jurnal Manajemen Bisnis dan Publik. 2011;1(1):17-30.

15. Fatmawati AD. Hubungan Pemberian Penghargaan dengan Motivasi Kerja
Perawat Pelaksana di Ruang Rawat Inap Kelas III Rumah Sakit Umum Daerah Raa Soewondo Pati. Ejournal Keperawatan. 2016;2(3):1-20.

16. Sitinjak EO, Wardhana A. Pengaruh Motivasi Terhadap Kinerja Perawat Pada Instalasi Paviliun Anyelir Rumah Sakit Budi Kemuliaan Batam. Ners Jurnal Keperawatan. 2016;3(1):581-588.

17. Desriana, Ani, Waluyo HD, Widayanto. Pengaruh Budaya Organisasi, Aktualisasi Diri, dan Penghargaan terhadap Prestasi Kerja Karyawan PT. Kereta Api Indonesia (Persero) DAOP IV Semarang. Diponegoro Journal of Social and Political of Science. 2014;4(1):1-9.

18. Sari. Hubungan Penghargaan dengan Kinerja Perawat Pelaksana di Rumah Sakit Haji Medan. Ejournal Ilmu Administrasi Bisnis. 2013;1(1):41-55.

19. Royani, et al. Sistem Penghargaan terhadap Kinerja Perawat Melaksanakan Asuhan Keperawatan. Jurnal Keperawatan Indonesia. 2012;1(5):129-136.

20. Makta LO. Pengaruh Motivasi Kerja dengan Kinerja Perawat Pelaksana di Unit Rawat Inap RS Stella Maris Makasar 2013. Skripsi. Universitas Hasanuddin. Makasar; 2013. 